\title{
Malnutrition amongst HIV adult patients in selected hospitals of Bushenyi district in southwestern Uganda
}

\author{
Ambrose Odwee ${ }^{1,2}$, Keneth Iceland Kasozi ${ }^{3}$, Christine Amongi Acup ${ }^{1}$, Patrick Kyamanywa ${ }^{2}$, \\ Robinson Ssebuufu ${ }^{2}$, Richard Obura ${ }^{4}$, Jude B Agaba ${ }^{1}$, Danladi Makeri ${ }^{1}$, Claude Kirimuhuzya ${ }^{5,6}$, \\ Olivia Sasirabo ${ }^{4}$, Pwaveno H Bamaiyi ${ }^{1,7,8}$
}

1. Department of Public Health, School of Allied Health and Sciences, Kampala International University Teaching Hospital, Box 71, Bushenyi, Uganda.

2. Department of Surgery, Faculty of Clinical Medicine and Dentistry, Kampala International University Teaching Hospital, Box 71, Bushenyi, Uganda.

3. Department of Physiology, Faculty of Biomedical Sciences, Kampala International University Western Campus, Box 71, Bushenyi, Uganda.

4. School of Business and Management, Mountains of the Moon University, Box 837, Fort Portal, Uganda.

5. Department of Pharmacology, School of Pharmacy, Kampala International University Western Campus, Box 71 Bushenyi, Uganda.

6. Department of Pharmacology, School of Medicine, Kabale University, Kabale, Uganda.

7. Postgraduate School and Research Directorate, Kampala International University Western Campus, Box 71, Bushenyi, Uganda.

8. Department of Veterinary Public Health and Preventive Medicine, Faculty of Veterinary Medicine, University of Jos, Plateau State, Nigeria.

\begin{abstract} factors.

Keywords: Malnutrition, HIV adult patients, Bushenyi district,Uganda.

DOI: https://dx.doi.org/10.4314/ahs.v20i1.17

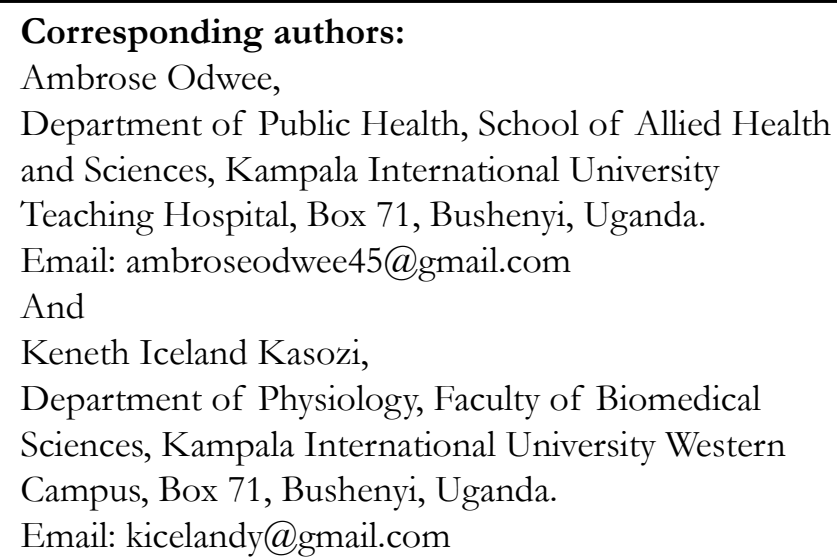

Background: Malnutrition is an important clinical outcome amongst HIV patients in developing countries and in Uganda, there is scarcity of information on its prevalence and risk factors amongst HIV adult patients.

Methods: A cross-sectional study amongst 253 HIV patients in Bushenyi district assessed their nutritional status using the body mass index (BMI) and mid-upper arm circumference (MUAC), and a questionnaire was used to identify major risk

Results: The mean age of the study participants was $38.74 \pm 0.80 \mathrm{yrs}$, while females and males were $52.2 \%$ and $47.8 \%$ respectively. Prevalence of malnutrition was 10.28\% (95\% CI: 6.82 - 14.69) in the study. Major socio-economic factors associated with malnutrition were being female, unemployed, dependent and with many family members. Patients with opportunistic infections, low adherence to HAART, and stage of HIV/AIDS had a higher risk of malnutrition

Discussion: In rural communities, a majority of malnourished patients are elderly and these were identified as priority groups for HIV outreach campaigns. The current policy of prioritizing children and women is outdated due to changing disease dynamics, thus showing a need to revise extension service provision in rural communities.

Conclusions: Malnutrition is a threat in HIV adult patients in rural communities of Uganda.

Cite as: Odwee A, Kasozi KI, Acup CA, Kyamanywa P, Ssebunfu R, Obura R, et al. Malnutrition amongst HIV adult patients in selected hospitals of Bushenyi district in southwestern Uganda. Afri Health Sci. 2020;20(1):122-31. bttps:// dx.doi.org/10.4314/ abs.v20i1.17

\section{Introduction}

Malnutrition amongst HIV/AIDS patients is a major challenge to the attainment of the sustainable development goals ${ }^{1}$. This is important since severe malnutrition creates increased strain on the already overstrained healthcare systems once these patients are admitted ${ }^{2}$. In Northern Uganda, a prevalence of $15.4 \%$ has been found present amongst HIV-positive mothers and children $^{3}$. In Bushenyi district, a malnutrition prevalence of 46\% amongst HIV positive children has been shown to exist ${ }^{4}$. These observations seem to be contradicto-

(C) 2020 Odwee A et al. Licensee African Health Sciences. This is an Open Access article distributed under the terms of the Creative commons Attribution License (https://creativecommons.org/licenses/BY/4.0), which permits unrestricted use, distribution, and reproduction in any medium, provided the original work is properly cited. 
ry since Uganda is internationally known for her fertile soils and high food productivity. In southwestern Uganda, malnutrition has been shown to be related to low protein intake, due to limited information on child health feeding, low socio-economic status, household size, poor hygiene and lack of special feed supplements for children ${ }^{5}$. This emphasis on children has subsequently led to an unintentional neglect of the adult-elderly population. This is important since $8.5 \%(12,000)$ of the population in Bushenyi district is HIV positive $e^{6,7}$, showing a need to revise current extension prioritization activities in several rural communities of Uganda to improve patient outcomes since a compromised immunity following HIV infection can easily lead to a grave prognosis once malnutriton is poorly handled ${ }^{8}$.

A majority of HIV patients in developing countries struggle with psychological stress, which would be a result of community/household neglect, thus forcing patients to live alone ${ }^{9}$. HIV patients have a high financial burden as they struggle to control opportunistic infections associated with the disease ${ }^{10}$. This implies that a majority of the patients are poor, and would often not be able to work, thus a low economic status, and unable to buy nutritional supplements ${ }^{11}$. This situation would also be complicated by an inefficient extension system which systematically neglects adults over children in the provision of nutrition counseling services ${ }^{12,13}$. This is especially true in rural communities since HIV patients with opportunistic infections have been associated with an increased risk to malnutrition ${ }^{14}$, showing the importance of location in affecting patient outcomes within Africa. In Zimbabwe, HAART has been associated with overweight especially amongst females ${ }^{15}$, demonstrating its influence on the nutritional status of patients. In addition, malnutrition is determined by the food eaten by an individual ${ }^{16}$, and a low social economic status would make access to a balanced diet challenging ${ }^{17-19}$. Uganda currently lacks its own national cut off limits for the diagnosis of malnutrition and the use of the World Health Organization body mass index (BMI) is key ${ }^{20}$, however, relationships between the waist-hip ratio (WHR) and BMI for Africans are currently unreliable ${ }^{21}$, showing a need for more studies. In Africa, HIV community intervention activities have recently ignored adults and this would make it challenging for the attainment of the SDGs since adults are more at risk than children ${ }^{6,22}$. In Uganda, HAART has reduced HIV transmission especially to children from mothers ${ }^{23,24}$. However, scarcity of data on undernutrition from HIV-positive adults on HAART in rural communities of Uganda. This was im- portant since weight loss has been shown to be highly prevalent amongst HIV patients on HAART ${ }^{25,26}$. The objective of the current study was to establish the malnutrition prevalence amongst HIV adult patients and identify major risk factors in Bushenyi district of southwestern Uganda.

\section{Materials and methods \\ Study design}

This was a cross-sectional study conducted amongst HIV adult patients in selected hospitals of Bushenyi District. The study was conducted at Kampala International University Teaching Hospital (KIU-TH), Ishaka Adventist Hospitals and Comboni Hospital since they all have an active ART clinic and conduct extension activities in rural communities of Bushenyi district.

\section{Sample size determination}

The prevalence of malnutrition among HIV- positive adults on ART in Uganda by 2011 was at $15.4 \%{ }^{3}$. The sample size was determined using the equation below

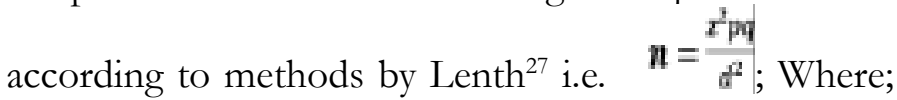
$\mathrm{n}$ - desired sample size; $\mathrm{z}$ - standard deviation at 95\% degree of accuracy i.e. 1.96; $\mathrm{p}$ - proportion of adults receiving HIV/AIDS care in health facilities i.e. 15.4\% $=0.154 ; \mathrm{q}=1-\mathrm{p}, \mathrm{q}=0.846 ; \mathrm{d}-$ acceptable margin of error which was set at $5 \%=0.05$, and a total of 253 participants were included in the study. Patients included in the study were chosen randomly by assigning each a random number. All those with even numbers were included in the study.

\section{Data collection method}

Malnutrition was diagnosed by determining the body mass index (BMI) of the study participants. BMI was measured using the body weight $(\mathrm{Kg}) /$ height $\left(\mathrm{m}^{2}\right)$ of each participant. BMI was categorized into underweight (severe, mild and moderate thinness), normal and overweight using World Health Organization categories $^{28}$ and these were the outcome variables. In addition, MUAC for diagnosis of malnutrition was done using an international limit of $<23$ for the presence of malnutrition $^{29}$, due to a lack of local national reference values. Using a semi-structured questionnaire, information on demographic characteristics like age, sex, as well as body weight and height, waist-hip ratio (WHR) were assessed. The WHR cut off limit used for underweight $<0.85$ was used $^{21}$, since a majority of reference cutoffs are for obesity ${ }^{30}$. In addition, nutritional variables on food type, source, and frequency as well as the ability to save money per month were investigated. 


\section{Statistical analysis}

Data were entered in MS Excel, exported to SPSS Version 20 for analysis. Information was descriptively presented as frequencies (percentages), mean \pm SEM. Simple and multiple linear regression were conducted to predict relationships amongst variables, followed by a multiple logistic regression as well as a One Way ANOVA when applicable. The odds ratios were reported at a 95\% confidence interval and the $\mathrm{P}$ values for each independent socio-economic, nutritional and dietary variable were compared against the first category for the presence of malnutrition. To avoid confounding, all variables were analyzed together for their association and significance was reported when a $\mathrm{P}<0.05$.

\section{Results}

\section{Description of the study population}

The mean age of the study participants was $38.77 \pm$ $0.79 \mathrm{yrs}$, in which $84.2 \%$ of the participants had their age in the range of $18-54$ yrs. Also, a majority were single $(62.5 \%) .39 .9 \%$ had a primary level of education as shown in Table 1.

Table 1 Description of the study population in Bushenyi district of Uganda.

\begin{tabular}{llcc}
\hline Parameter & Variable & $\mathrm{N}$ & Statistic \\
\hline \multirow{2}{*}{ Age in years } & Value & 253 & $38.77 \pm 0.79^{\mathrm{a}}$ \\
& $18-35$ & 122 & $48.2 \%$ \\
& $36-54$ & 91 & $36.0 \%$ \\
Marital status & Married & 40 & $15.8 \%$ \\
& Single & 95 & $37.5 \%$ \\
Sex & Females & 158 & $62.5 \%$ \\
& Males & 132 & $52.2 \%$ \\
Education & None & 121 & $47.8 \%$ \\
level & Primary & 22 & 8.7 \\
& Secondary & 101 & 39.9 \\
& Tertiary & 76 & 21.3
\end{tabular}

KEY: Statistics conducted $\mathrm{a}=$ mean \pm SEM while all other parameters are presented as percentages.

Prevalence of malnutrition in the study area.

The study showed that prevalence of malnutrition was $10.59 \%$ (95\% CI: 4.96, 19.15) at Kampala Internation- al University Teaching hospital, 3.61\% at SDA hospital and 16.47\% (95\% CI: 9.31, 26.09) at Comboni hospital leading to an overall malnutrition prevalence of $10.28 \%$ as shown in Table 2.

Table 2 Prevalence of malnutrition in selected hospitals amongst adult HIV patients of Uganda

\begin{tabular}{lcccc}
\hline Location & $\begin{array}{c}\text { No. of } \\
\text { malnourished } \\
\text { participants }\end{array}$ & $\begin{array}{c}\text { Total no. of } \\
\text { participants }\end{array}$ & $\begin{array}{c}\text { Prevalence of } \\
\text { malnutrition }\end{array}$ & $\begin{array}{c}\text { interval } \\
\text { KIU-TH }\end{array}$ \\
SDA & 3 & 85 & 10.59 & $4.96-19.15$ \\
Comboni & 14 & 83 & 3.61 & $0.75-10.20$ \\
\hline Overall & 26 & 85 & 16.47 & $9.31-26.09$ \\
\hline
\end{tabular}


In addition, the mean waist-hip ratio for the presence of under and over nutrition was $0.855 \pm 0.011$ and $0.834 \pm 0.012$ respectively while mean BMI for under and overnourished patients was $16.981 \pm 0.191$ and
$30.06 \pm 0.994$ respectively. Furthermore, mean MUAC was $22.65 \pm 0.380 \mathrm{~cm}$ and $27.49 \pm 0.560 \mathrm{~cm}$ for under and overnutrition in which significant differences were found $(\mathrm{P}<0.05)$ as shown in Table 3.

Table 3 Mean WHR, BMI and MUAC in malnutrition among study participants.

\begin{tabular}{lccc}
\hline Malnutrition & \multicolumn{3}{c}{ Malnutrition } \\
\cline { 2 - 3 } index & \multicolumn{2}{c}{ Pbsent } & P values \\
\cline { 2 - 3 } & \multicolumn{3}{c}{ Mean \pm SEM } \\
\hline WHR & $0.835 \pm 0.005$ & $0.855 \pm 0.011$ & 0.158 \\
BMI $\left(\mathrm{kg} / \mathrm{m}^{2}\right)$ & $24.032 \pm 0.380$ & $16.981 \pm 0.191$ & 0.000 \\
MUAC $(\mathrm{cm})$ & $25.54 \pm 0.213$ & $22.65 \pm 0.380$ & 0.000 \\
\hline
\end{tabular}

The study further on showed that mild thinness was most prevalent in the undernourished population
(5.1\%) and among these, males had an odds of 0.937 ( $95 \%$ CI: $0.1114-7.728$ ) of mild thinness as shown in Table 4.

Table 4 Malnutrition level, odds ratios and distribution amongst female and male participants.

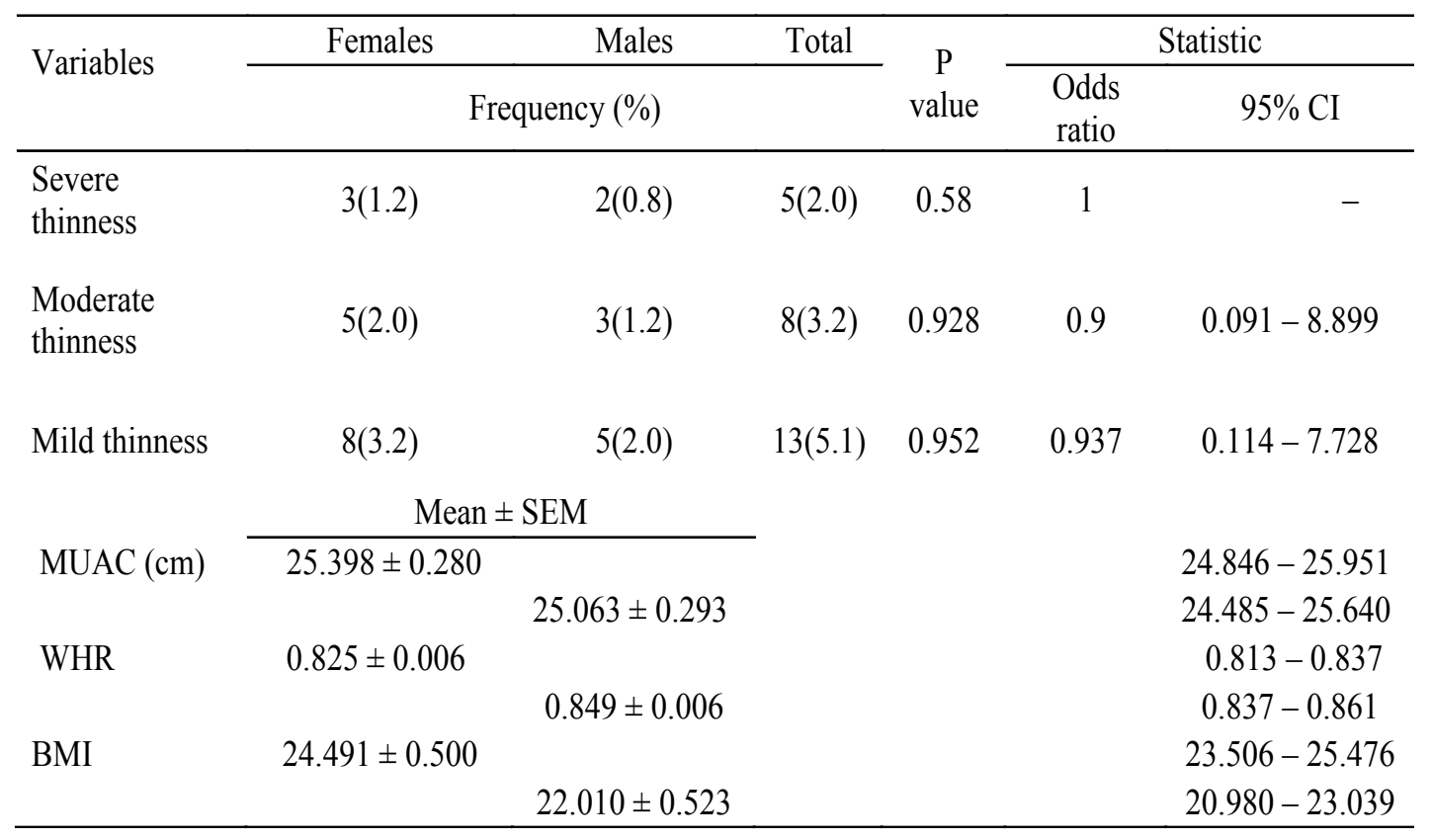

Simple linear regression showed a low relationship between WHR and BMI (WHR $=0.849-0.001$ BMI, R $=0.043, \mathrm{R} 2=0.002, \mathrm{P}=0.498)$. A multiple regression was run to predict WHR from sex, age, MUAC and BMI. These variables significantly predicted WHR, F $(4,246)=2.889, \mathrm{P}=0.023, \mathrm{R} 2=0.045$. All four variables didn't add up statistically significantly to the prediction equation i.e. WHR $=0.778+0.001$ age +0.20 sex +0.000 MUAC $-0.000084 \mathrm{BMI}(\mathrm{P}$ value for age $=$ $0.59, \mathrm{P}$ value sex $=0.026, \mathrm{P}$ value $\mathrm{BMI}=0.919, \mathrm{P}$ value
MUAC $=0.904)$ since gender was the only variable statistically significant. In addition, logistic regression was performed to determine effects of undernutrition (dependent variable), age, MUAC and WHR amongst HIV patients. The logistic regression model was statistically significant, $\mathrm{X} 2(4)=14.854, \mathrm{P}=0.038$. The model explained $14.9 \%$ (Negelkerke, R2) of the variance in malnourished population and correctly classified $87.9 \%$ of the cases. The odds of being malnourished was $47.9 \%$ greater in females than males. 
Major socio-economic factors associated with malnutrition among HIV patients in Uganda.

The occurrence of malnutrition was common amongst females, who were least educated and consumed alcohol as compared to males, showing that this is the major social group associated with malnutrition. In addition, the odds of being malnourished were $75.7 \%$ greater amongst unemployed (95\% CI: 0.724 - 4.264) than the employed. In addition, patients who relied heavily on private sponsors to help them acquire medications had an $8 \mathrm{x}$ risk of getting undernourished when compared against those who get free medications provided by the government. The only independent variable significantly associated with malnutrition in this population was payment for drugs as shown in Table 5.

Table 5 Major socio-economic risk factors associated with malnutrition in Bushenyi.

\begin{tabular}{|c|c|c|c|c|c|c|c|}
\hline \multirow[t]{2}{*}{ Parameter } & \multirow[t]{2}{*}{ Variable } & \multicolumn{3}{|c|}{$\begin{array}{c}\text { Frequency (\%) of participants with } \\
\text { under nutrition }\end{array}$} & \multirow[t]{2}{*}{$\begin{array}{c}P \\
\text { value }\end{array}$} & \multicolumn{2}{|c|}{ Odds ratio } \\
\hline & & Absent & Present & Total & & Value & $95 \% \mathrm{CI}$ \\
\hline \multirow[t]{2}{*}{ Sex } & Female & $116(46.0)$ & $15(6.0)$ & $131(52.0)$ & & 1 & - \\
\hline & Male & $111(44.0)$ & $10(4.0)$ & $121(48.0)$ & 0.430 & 0.695 & $0.282-1.714$ \\
\hline \multirow{4}{*}{$\begin{array}{l}\text { Education } \\
\text { level }\end{array}$} & None & $16(6.3)$ & $5(2.0)$ & $21(8.3)$ & 0.205 & 1 & - \\
\hline & Primary & $92(36.5)$ & $9(3.6)$ & $101(40.1)$ & 0.125 & 0.372 & $0.105-1.328$ \\
\hline & Secondary & $71(28.2)$ & $5(2.0)$ & $76(30.2)$ & 0.079 & 0.283 & $0.069-1.155$ \\
\hline & Tertiary & $48(19.0)$ & $6(2.4)$ & $54(21.4)$ & 0.746 & 0.784 & $0.180-3.414$ \\
\hline \multirow{3}{*}{$\begin{array}{l}\text { Marital } \\
\text { status }\end{array}$} & Married & $90(35.7)$ & $5(2.0)$ & $95(37.7)$ & & 1 & - \\
\hline & Single & $137(54.4)$ & 20(7.9) & $157(62.3)$ & 0.070 & 2.563 & $0.926-7.095$ \\
\hline & Alcohol & $51(20.2)$ & $11(4.4)$ & $62(24.6)$ & 0.407 & 1 & - \\
\hline \multirow[t]{3}{*}{ Lifestyles } & Smoking & $19(7.5)$ & $0(0)$ & $19(7.5)$ & 0.998 & 0.000 & - \\
\hline & Drug abuse & $8(3.2)$ & $0(0)$ & $8(3.2)$ & 0.998 & 0.000 & - \\
\hline & Never & $149(59.1)$ & $14(5.6)$ & $163(64.7)$ & 0.088 & 0.459 & $0.187-1.124$ \\
\hline \multirow[t]{2}{*}{ Employed } & Yes & $161(63.9)$ & $16(6.3)$ & $177(70.2)$ & - & 1 & - \\
\hline & No & $66(26.2)$ & $9(3.6)$ & $75(29.8)$ & 0.212 & 1.757 & $0.724-4.264$ \\
\hline \multirow[t]{2}{*}{ Savings } & Possible & $42(17.8)$ & $6(2.5)$ & $48(20.3)$ & - & 1 & - \\
\hline & Impossible & $170(72.0)$ & $18(7.6)$ & $188(79.7)$ & 0.488 & 0.704 & $0.261-1.898$ \\
\hline
\end{tabular}

Major health risk factors associated with malnutrition in the study population.

Malnutrition was most prevalent amongst participants who had Stage $2 \mathrm{HIV} / \mathrm{AIDS}$, although the odds were lower $(\mathrm{OR}=0.329,95 \% \mathrm{CI}: 0.136-0.796)$ when compared to those in Stage 1. Failure to adhere to HAART was high and the odds were 3 times greater for malnutrition (OR: 2.956, 95\% CI: 0.383 - 22.801) when compared to those who were adhering to the therapy, although these were not significant. Also, the presence of more than one opportunistic infection in the last 6 months increased the risk of developing malnutrition more than two times (OR $=2.452$; 95\% CI: 0.835 7.207) than those who had none during this period, and these were incidental findings. Furthermore, a majority $(17 / 26)$ of the malnourished participants never exercised and these had a higher chance of developing under malnutrition as compared to those who regularly exercised. In addition, a unit increase in family dependent members in a homestead increased (OR $=1.204,95 \%$ CI: $0.711-2.039)$ the risk of malnutrition by $20.4 \%$ as shown in Table 6. 
Table 6 Major health risk factors in the study population associated with malnutrition.

\begin{tabular}{|c|c|c|c|c|c|c|c|}
\hline \multirow[t]{2}{*}{ Parameter } & \multirow[t]{2}{*}{ Variable } & \multicolumn{3}{|c|}{$\begin{array}{c}\text { Frequency }(\%) \text { of participants with under } \\
\text { nutrition }\end{array}$} & \multirow[t]{2}{*}{$\begin{array}{c}\mathrm{P} \\
\text { value }\end{array}$} & \multicolumn{2}{|c|}{ Odds ratio } \\
\hline & & Absent & Present & Total & & Value & $95 \% \mathrm{CI}$ \\
\hline \multirow[t]{3}{*}{ AIDS stage } & Stage 1 & $88(34.8)$ & $18(7.1)$ & $106(41.9)$ & 0.048 & 1 & \\
\hline & Stage 2 & $121(47.8)$ & $8(3.2)$ & $129(51.0)$ & 0.014 & 0.329 & $0.136-0.796$ \\
\hline & Stage 3 & $18(7.1)$ & $0(0)$ & $18(7.1)$ & 0.998 & 0.000 & - \\
\hline \multirow[t]{2}{*}{ Health counselling } & Yes & $204(81.0)$ & $24(9.5)$ & $228(90.5)$ & & 1 & - \\
\hline & No & $22(8.7)$ & $2(0.8)$ & $24(9.5)$ & 0.739 & 0.771 & $0.167-3.556$ \\
\hline \multirow[t]{2}{*}{ Adherence to HAART } & Yes & $24(9.5)$ & $1(0.4)$ & $25(9.9)$ & & 1 & - \\
\hline & No & 203(80.3) & $25(9.9)$ & $228(90.1)$ & 0.299 & 2.956 & $0.383-22.801$ \\
\hline \multirow[t]{2}{*}{ Opportunistic infections } & None & $206(81.7)$ & $21(8.3)$ & $227(90.1)$ & & 1 & \\
\hline & $=1$ & $20(7.9)$ & $5(2.0)$ & $25(9.9)$ & 0.103 & 2.452 & $0.835-7.207$ \\
\hline \multirow[t]{2}{*}{ Freq. of exercise } & Often & $89(35.2)$ & $9(3.6)$ & $98(38.7)$ & & 1 & - \\
\hline & Never & $138(54.5)$ & $17(6.7)$ & $155(61.3)$ & 0.949 & 1.029 & $0.430-2.461$ \\
\hline Mean patients at home & & $1.68 \pm 0.14$ & $1.12 \pm 0.29$ & $0.184^{\mathrm{a}}$ & 0.388 & 0.807 & $0.496-1.314$ \\
\hline
\end{tabular}

Major nutritional risk factors associated with malnutrition in the study population

A majority of the participants claimed to eat a balanced diet, and these had 51.9\% less likelihood (OR $=0.491$, $95 \%$ CI: $0.183-1.315$ ) of developing malnutrition as compared to those who fed on a main carbohydrate diet. In addition, a low risk was associated with eating more than one meal a day, showing that eating a few meals per day would increase the risk of one being undernourished. In addition, abstinence from nutritional supplements increased the risk to malnutrition $(\mathrm{OR}=$ 2.934, 95\% CI: $0.636-13.542)$ as shown in Table 7. 
Table 7 Major nutritional risk factors in the study population to malnutrition.

\begin{tabular}{|c|c|c|c|c|c|c|c|}
\hline \multirow[t]{2}{*}{ Parameter } & \multirow[t]{2}{*}{ Variable } & \multicolumn{3}{|c|}{$\begin{array}{c}\text { Frequency }(\%) \text { of participants with } \\
\text { under nutrition }\end{array}$} & \multirow{2}{*}{$\begin{array}{c}\mathrm{P} \\
\text { value }\end{array}$} & \multicolumn{2}{|c|}{ Odds ratio } \\
\hline & & Absent & Present & Total & & Value & $95 \% \mathrm{CI}$ \\
\hline \multirow[t]{5}{*}{ Major food } & Carbohydrates & $54(21.3)$ & $12(4.7)$ & $66(26.1)$ & 0.570 & 1 & \\
\hline & Fast foods & $9(3.6)$ & $1(0.4)$ & $10(4.0)$ & 0.921 & 0.892 & $0.093-8.503$ \\
\hline & Balanced diet & $157(62.1)$ & $13(5.1)$ & $170(67.2)$ & 0.157 & 0.491 & $0.183-1.315$ \\
\hline & Protein & $7(2.8)$ & $0(0)$ & $7(2.8)$ & 0.999 & 0.000 & - \\
\hline & One & $4(1.6)$ & $1(0.4)$ & $5(2.0)$ & 0.752 & 1 & - \\
\hline \multirow[t]{3}{*}{ No. of daily meals } & Two & 139(55.6) & $20(8.0)$ & $159(63.6)$ & 0.406 & 0.329 & $0.024-4.527$ \\
\hline & Three & $71(28.4)$ & $5(2.0)$ & $76(30.4)$ & 0.295 & 0.222 & $0.013-3.715$ \\
\hline & Four & $10(4.0)$ & $0(0)$ & $10(4.0)$ & 0.999 & 0.000 & - \\
\hline \multirow{2}{*}{$\begin{array}{l}\text { Nutritional } \\
\text { supplements taken }\end{array}$} & Often & $59(23.3)$ & $2(0.8)$ & $61(24.1)$ & - & 1 & - \\
\hline & Never & $168(66.4)$ & $24(9.5)$ & 192(75.9) & 0.168 & 2.934 & $0.636-13.542$ \\
\hline \multirow{2}{*}{$\begin{array}{l}\text { Nutritional } \\
\text { counselling }\end{array}$} & Yes & $137(54.2)$ & $15(5.9)$ & $152(60.1)$ & - & 1 & - \\
\hline & No & $90(35.6)$ & $11(4.3)$ & 101(39.9) & 0.685 & 1.230 & $0.453-3.715$ \\
\hline \multirow[t]{3}{*}{ Major food source } & Farm & 103(40.7) & $9(3.6)$ & $112(44.3)$ & 0.848 & 1 & - \\
\hline & Local shops & $119(47.0)$ & $17(6.7)$ & $136(53.8)$ & 0.565 & 1.313 & $0.519-3.323$ \\
\hline & Government & $5(2.0)$ & $0(0)$ & $5(2.0)$ & 0.000 & 0.000 & - \\
\hline
\end{tabular}

\section{Discussion}

The mean age of the study participants was $38.74 \pm$ 0.80 years showing that this was a predominantly adult population (Table 1). In East Africa, the role of adults in the propagation of HIV has been recognized ${ }^{31}$, showing their importance in understanding the disease burden in the general population since elderly persons have been shown to be at risk of developing malnutrition $^{32}$. The study showed an overall malnutrition prevalence of $10.28 \%$ (Table 2) and this was lower than that reported in Northern Uganda amongst HIV patients ${ }^{3}$. This was important since previous studies in Bushenyi district had placed a lot of emphasis on children ${ }^{4}$ while neglecting adults. Findings in the current study show that malnutrition may not necessarily be age specific, but diffuse in a majority of rural communities with a high HIV patient load. This is because the current prevalence is lower than that reported in Mbarara Regional Referal Hospital (South Western Uganda) and Mulago
National Referral Hospital (Central Uganda), showing that the disease burden affects the entire HIV population irrespective of age $e^{9,33-35}$. In addition, the prevalence reported in Uganda is lower than that in Ethiopia $(25.2 \%)$ on undernutrition ${ }^{14,36}$, showing that HIV patients in Uganda are relatively healthier than those in neighboring East African nations thus providing information from this study which would guide policy in the management of HIV patients of Uganda.

In the current study, the use of BMI and MUAC as variables for the diagnosis of malnutrition was re-emphasized due to significant differences being identified between presence and absence of the disease (Table 3). These findings are in agreement with previous findings which showed their relevance in the clinical diagnosis of nutritional status in patients ${ }^{37}$. A majority of malnourished patients were in the mild stage of thinness (Table 3) and this was similar to findings in Ethiopia 
amongst HIV patients ${ }^{14}$. This was important since the prognosis of malnourished patients with HIV and AIDS has been shown to be affected by the quality of patient treatment ${ }^{38}$. Furthermore, there was a low relationship between WHR and BMI which was similar to findings from Nigeria ${ }^{21}$, showing key similarities in the African context and justifying a need for Uganda to develop her local WHR cut offs. For the Ugandan population, MUAC mean scores of $22.65 \pm 0.380 \mathrm{~cm}$ (Table 4) were associated with malnutrition $(\mathrm{X} 2(4)=$ 14.854, $\mathrm{P}=0.038$ ), showing a need for local national MUAC reference values for the promotion of patient care. In this HIV positive population, elderly women were found to be more at risk of getting malnourished, showing the need to target elderly women in community intervention activities in the adult HIV population, thus reversing current prioritization efforts on children for the promotion of the SDGs in Uganda ${ }^{1,39,40}$.

Major socio-economic factor associated $(\mathrm{P}<0.05)$ with undernutrition amongst HIV patients was depending on a sponsor to access medications for opportunities infections (Table 5), however, incidental findings such as being female, illiterate and an alcoholic as well as unemployed were identified in the community ( $\mathrm{P}>0.05)$. In Uganda, the emphasis had been placed on children on malnutrition studies ${ }^{8,33}$, however, this study shows that a low social background predisposes adult HIV patients to malnutrition. These findings are in agreement with those in Ethiopia in which poverty and illiteracy were identified as key risk factors to malnutrition ${ }^{41}$. These observations show that disadvantaged persons need to be supported with income-generating activities so that their reliance on third parties (usually relatives) to buy medications is reduced as this would help reduce on the malnourished population and reduce on the health care burden ${ }^{10}$. Community education and economic activities which would improve on the patient status of living would be promoted in prospective extension activities within the district ${ }^{12}$. This would help protect patients against protein-energy malnutrition (PEM), which has been shown to be highly prevalent in developing countries $^{42}$.

Major health risk factors associated $(\mathrm{P}<0.05)$ with malnutrition amongst HIV adult patients identified in the study were stage 1, Stage 2 HIV/AIDS and mean number of family members (Table 6 ). In addition, the study identified $(\mathrm{P}>0.05)$ low adherence to HAART, not exercising and presence of opportunistic infections. These observations show that undernourished patients are often persons who would be dealing with the stigma of HIV/AIDS since these often have a low adherence to HAART as compared to those who have already accepted the disease and are continually on therapy ${ }^{43}$. In addition, clinical examination may not necessarily correlate with the health status of the patient ${ }^{44}$, showing that an undernourished HIV patient may not necessarily be with advanced HIV/AIDS. In the United Kingdom, a study amongst HIV positive Ugandans showed that late presentation of patients was associated with high opportunistic infections ${ }^{45}$, demonstrating the effect of socio-economic status on patient health outcomes. This situation would be aggravated in rural communities of Uganda due to the low health care coverage and quality associated with several developing countries ${ }^{6,22}$.

Nutritionally, the presence of malnutrition was high in HIV/AIDS patients who had carbohydrates as their major food, eating once a day and no food supplements being taken (Table 7). High carbohydrate foods would predispose patients in this community to protein-energy malnutrition which is highly prevalent in devloping countries like Uganda ${ }^{42}$. It appears the low socio-economic status makes it difficult for undernourished HIV adult patients to access highly protein foods (such as milk, beef and eggs) and local foods like bananas and millet continue to constitute their major dietary source, leading to a high disease burden in a region associated with plentiful animal protein sources ${ }^{5}$. It appears malnourished in rural communities of Southwestern Uganda amongst HIV and AIDS patients would be due to poor household nutritional practices ${ }^{5}$, showing a need for a revision in the outreach community activities in affected communities.

\section{Conclusion}

The study showed that undernutrition amongst HIV positive adult patients is a major public health threat. Most at risk groups are patients who are women, dependents, patients with stage 1 and 2 HIV. Major changes in extension service provision, by including adults in affected communities would help alleviate the problem at hand. Community education on nutritional supplementation, and engagement in economic activities, which improve their standards of living, would lead to improved patient outcomes.

\section{Declarations \\ Ethical approval}

Institutional ethical approval number Nr-UGREC-023/2017/04 and clearance from the Uganda National Council of Science and Technology number 
HS 2434 were acquired prior to the commencement of the study while informed consent was acquired from each participant.

\section{Author's contributions}

All authors contributed equally to this work. A.O; K.I.K; C.A.A; P.K; P.H.B designed the study, A.O; R.O; A.B.J; O.S collected the data while A.O; K.I.K; R.S; P.H.B conducted data analysis. A.O; K.I.K; C.K prepared an initial manuscript and A.O; K.I.K; C.A.A, R.S; R.O; A.B.J; C.K; O.S; P.K; P.H.B read and approved final version for submission.

\section{Data availability}

Information can be found at https://figshare.com/s/ b431981d5184b356aff9

\section{Conflict of interest}

Authors declare no conflict of interest exists.

\section{Funding}

No research grant was acquired for this work.

\section{References}

1. Kimani-Murage EW, Norris SA, Pettifor JM, Tollman SM, Klipstein-Grobusch K, Gómez-Olivé XF, et al. Nutritional status and HIV in rural South African children. BMC Pediatr. 2011;11.

2. Prendergast A, Bwakura-Dangarembizi MF, Cook AD, Bakeera-Kitaka S, Natukunda E, Nahirya Ntege $\mathrm{P}$, et al. Hospitalization for severe malnutrition among HIV-infected children starting antiretroviral therapy. AIDS. 2011;25(7):951-6.

3. Ahoua L, Umutoni C, Huerga H, Minetti A, Szumilin E, Balkan S, et al. Nutrition outcomes of HIV-infected malnourished adults treated with ready-to-use therapeutic food in sub-Saharan Africa: A longitudinal study. J Int AIDS Soc. 2011;14(1):2.

4. Agaba E, Kikafunda J, Bambona. malnutrition amidast plenty: as assesment of factors responsible for persistent high leves of childhood stunting in food secure western Uganda. African J Food, Agriculture,nutrition Dev. 2014;14(5):2088-113.

5. Kikafunda JK, Agaba E, Bambona A. Malnutrition Amidst Plenty: an Assessment of Factors Responsible for Persistent High Levels of Childhood Stunting in Food Secure Western Uganda. African J Food Agric Nutr Dev. 2014;14(5):9288-313.

6. UNAIDS. Uganda: Developing Estimates of HIV Prevalence and the Number of People Living With HIV. Uganda; 2014. p. 10.
7. CDC, ICAP, Health M of. uganda population based HIV impact assessment. Kampala; 2017.

8. Magadi M a. Household and community HIV/AIDS status and child malnutrition in sub-Saharan Africa: evidence from the demographic and health surveys. Soc Sci Med. 2011;73(3):436-46.

9. Magadi MA. Cross-national analysis of the risk factors of child malnutrition among children made vulnerable by HIV/AIDS in sub-Saharan Africa: evidence from the DHS. Trop Med Int Heal. 2011;16(5):570-8.

10. Ezeonwumelu OJ, Muhammad N, Keneth IK, Steve OO, Julius KT, Ezera A, et al. Resistance, Minimum Inhibitory and Bactericidal Concentration Profiles of Oral Bacteria from HIV / AIDS Patients in South Western Uganda. BrJ Med Med Res. 2016;18(11).

11. Mundial B. HIV/AIDS, nutrition, and food security: what we can do: a synthesis of international guidance. In: HIV/AIDS, nutrition, and food security: what we can do: a synthesis of international guidance. Banco Mundial; 2007.

12. Kasozi KI, Echoru I, Mbiydzenyuy EN, Kimwise A, Nansunga M, Mutiat OA, et al. Community Education Challenges in Young Adults of South Western Uganda. Open J Epidemiol. 2015;5:65-70 PubMed .

13. UBOS and ICF. Uganda Demographic and Health Survey, 2011, Uganda UBOS and Calverton Merryland. Vol. 5, ICF International Inc. 2011.

14. Gedle D, Gelaw B, Muluye D, Mesele M. Prevalence of malnutrition and its associated factors among adult people living with HIV/AIDS receiving anti-retroviral therapy at Butajira Hospital, southern Ethiopia. BMC Nutr. 2015;1(1):5 PubMed .

15. Takarinda KC, Mutasa-Apollo T, Madzima B, Nkomo B, Chigumira A, Banda M, et al. Malnutrition status and associated factors among HIV-positive patients enrolled in ART clinics in Zimbabwe. BMC Nutr. 2017;3(1):15 PubMed .

16. Hills AP, Mokhtar N, Byrne NM. Assessment of physical activity and energy expenditure: an overview of objective measures. Front Nutr. 2014;1:5.

17. M DO, Monteiro C, Akré J, Clugston G. Global Database on Child Growth and Malnutrition The worldwide magnitude of protein $\neg$ energy malnutrition : an overview from the WHO Global Database on Child Growth. Bulletin of the World Health Organization. 2015.

18. Rai SK, Kazuko H, Ayako A, Yoshimi O. Infectious diseases and malnutrition status in Nepal: an overview. Malays J Nutr. 2002;8(2):191-200.

19. Tette EMA, Sifah EK, Nartey ET. Factors affecting malnutrition in children and the uptake of interventions to prevent the condition. BMC Pediatr. 2015;15(1):189. 
20. Kasozi KI, Mbiydzneyuy NE, Namubiru S, Safiriyu AA, Oluwadare SS, Okpanachi AO, et al. A study on visual, audio and tactile reaction time among medical students at Kampala International University in Uganda. Afr Health Sci. 2018;18(3):828-36.

21. Okafor C, Raimi T, Gezawa I, Sabir A, Enang O, Puepet F, et al. Performance of waist circumference and proposed cutoff levels for defining overweight and obesity in Nigerians. Ann Afr Med. 2016;15(4):185.

22. Taylor RY. Preventive nutrition: The comprehensive guide for health professionals. Vol. 2, British Medical Journal. 2001. 527 p.

23. Kaida A, Lima VD, Andia I, Kabakyenga J, Mbabazi P, Emenyonu N, et al. The WHOMEN's scale (Women's HAART Optimism Monitoring and EvaluatioN Scale v.1) and the association with fertility intentions and sexual behaviours among HIV-positive women in Uganda. AIDS Behav. 2009;13 Suppl 1:72-81.

24. Homsy J, Moore D, Barasa A, Were W, Likicho C, Waiswa B, et al. Breastfeeding, mother-to-child HIV transmission, and mortality among infants born to HIV-Infected women on highly active antiretroviral therapy in rural Uganda. J Acquir Immune Defic Syndr. 2010;53(1):28-35.

25. Mangili A, Murman DH, Zampini a M, Wanke C a. Nutrition and HIV infection: review of weight loss and wasting in the era of highly active antiretroviral therapy from the nutrition for healthy living cohort. Clin Infect Dis. 2006;42(6):836-42.

26. Kebede M, Haidar J. Factors influencing adherence to the food by prescription program among adult HIV positive patients in Addis Ababa, Ethiopia: a facility-based, cross-sectional study. Infect Dis Poverty. 2014 Jun;3(1):20.

27. Lenth R V. Some Practical Guidelines for Effective Sample Size Determination. Am Stat. 2001;55(3):18793.

28. World Health Organization. BMI classification. Pharmacotherapy. 2006;(Table 1):4-9.

29. Brito NB, Llanos JPS, Ferrer MF, García JGO, Brito

ID, Castro FP-G, et al. Relationship between mid-upper arm circumference and body mass index in inpatients. PLoS One. 2016;11(8).

30. World Health Organization. Waist Circumference and Waist-Hip Ratio. WHO Expert. 2011;64(1):2-5.

31. Kim AA, Hallett T, Stover J, Gouws E, Musinguzi J, Mureithi PK, et al. Estimating HIV incidence among adults in Kenya and Uganda: A systematic comparison of multiple methods. PLoS One. 2011;

32. Agarwal E, Miller M, Yaxley A, Isenring E. Malnutrition in the elderly: A narrative review. Maturitas. 2013.
33. Kikafunda JK, Namusoke HK. Nutritional status of HIV/AIDS orphaned children in households headed by the elderly in Rakai District, South Western Uganda. African J Food, Agric Nutr Dev. 2006;6(1):1-18.

34. Owor M, Tumwine JK, Kikafunda JK. Socio-economic risk factors for severe protein energy malnutrition among children in Mulago Hospital, Kampala. East Afr Med J. 2000;

35. Bachou H, Tylleskär T, Downing R, Tumwine JK. Severe malnutrition with and without HIV-1 infection in hospitalised children in Kampala, Uganda: Differences in clinical features, haematological findings and CD4+ cell counts. Nutr J. 2006;

36. Hadgu TH, Worku W, Tetemke D, Berhe H. Undernutrition among HIV positive women in Humera hospital, Tigray, Ethiopia, 2013: antiretroviral therapy alone is not enough, cross sectional study. BMC Public Health. 2013 Dec;13(1):943.

37. Sagun G, Oguz A, Karagoz E, Filizer A, Tamer G, Mesci B. Application of alternative anthropometric measurements to predict metabolic syndrome. Clinics. 2014;

38. Aquino RDC De, Philippi ST. Identification of malnutrition risk factors in hospitalized patients. Rev Assoc Med Bras. 2011;57(6):637-43.

39. Burgos R, Sarto B, Elío I, Planas M, Forga M, Cantón A, et al. Prevalence of malnutrition and its etiological factors in hospitals. Nutr Hosp. 2012;27(2):469-76.

40. Verbrugghe M, Beeckman D, Van Hecke A, Vanderwee K, Van Herck K, Clays E, et al. Malnutrition and associated factors in nursing home residents: A cross-sectional, multi-centre study. Clin Nutr. 2013;32(3):438-43. 41. Uthman OA. Prevalence and pattern of HIV-related malnutrition among women in sub-Saharan Africa: a meta-analysis of demographic health surveys. $B M C$ Public Health. 2008;8:226.

42. Müller $\mathrm{O}$, Krawinkel M. Malnutrition And Health In Developing Countries. Can Med Assoc J. 2005;173(3):279-86.

43. Mburu G, Ram M, Skovdal M, Bitira D, Hodgson I, Mwai GW, et al. Resisting and challenging stigma in Uganda : the role of support groups of people living with HIV. J Int AIDS Soc. 2013;16(Suppl 2):1-7.

44. Julius H, Basu D, Ricci E, Wing J, Basu JK, Pocaterra $\mathrm{D}$, et al. The burden of metabolic diseases amongst HIV positive patients on HAART attending The Johannesburg Hospital. Curr HIV Res. 2011;

45. O’Farrell N, Lau R, Yoganathan K, Bradbeer CS, Griffin GE, Pozniak AL. AIDS in Africans living in London. Genitourin Med. 1995. 